\title{
Major shifts in calcareous phytoplankton assemblages through the Eocene-Oligocene transition of Tanzania and their implications for low-latitude primary production
}

\author{
Tom Dunkley Jones, ${ }^{1}$ Paul R. Bown, ${ }^{2}$ Paul N. Pearson, ${ }^{3}$ Bridget S. Wade, ${ }^{4}$ \\ Helen K. Coxall, ${ }^{3}$ and Caroline H. Lear ${ }^{3}$ \\ Received 28 April 2008; revised 30 June 2008; accepted 18 July 2008; published 22 October 2008.
}

[1] A high-resolution record of exceptionally well preserved calcareous nannofossil assemblages from Tanzania is marked by two key transitions closely related to the climatic events of the Eocene-Oligocene transition (EOT). The first transition, at $\sim 34.0 \mathrm{Ma}$, precedes the first positive shift in $\delta^{18} \mathrm{O}$ and coincides with a distinct interval of very low nannofossil abundance and a cooling in sea surface temperatures (SST). The second, at $\sim 33.63 \mathrm{Ma}$, is immediately above the Eocene-Oligocene boundary (EOB) and is associated with a significant drop in nannofossil diversity. Both transitions involve significant reductions in the abundance of holococcoliths and other oligotrophic taxa. These changes in calcareous phytoplankton assemblages indicate (1) a widespread and significant perturbation to the low-latitude surface ocean closely tied to the EOB, (2) a potential role for reduced carbonate primary production at the onset of global cooling, and (3) a significant increase in nutrient availability in the low-latitude surface ocean through the EOT.

Citation: $\quad$ Dunkley Jones, T., P. R. Bown, P. N. Pearson, B. S. Wade, H. K. Coxall, and C. H. Lear (2008), Major shifts in calcareous phytoplankton assemblages through the Eocene-Oligocene transition of Tanzania and their implications for low-latitude primary production, Paleoceanography, 23, PA4204, doi:10.1029/2008PA001640.

\section{Introduction}

[2] The transition between the Eocene and Oligocene epochs is the central point of the most significant climatic shift of the Cenozoic, as the Earth's climate developed from the ice-free early Paleogene world of global warmth and high atmospheric $\mathrm{pCO}_{2}$ to the glaciated conditions of the early Oligocene with the rapid expansion of continentalscale ice sheets on Antarctica [Lear et al., 2000; Miller et al., 1991; Pagani et al., 2005; Zachos et al., 2001]. EoceneOligocene marine sedimentary records are characterized by large, $\sim 1.0$ to $1.5 \%$, positive excursions in benthic foraminiferal oxygen and carbon stable isotopes and a rapid deepening of the calcite compensation depth (CCD) [Coxall et al., 2005; Zachos et al., 1996]. Coincident with these changes in the deep sea, significant glaciomarine sedimentation commences around the margins of both East and West Antarctica indicating the first Cenozoic advance of continental-scale ice sheets in southern high latitudes [Breza and Wise, 1992; Ivany et al., 2006; Wise et al., 1991, 1992; Zachos et al., 1992]. Estimates of the increase in global ice volume through this transition, based on records of benthic foraminiferal $\delta^{18} \mathrm{O}, \mathrm{Mg} / \mathrm{Ca}$ ratios and sequence stratigraphy,

\footnotetext{
${ }^{1}$ Department of Geography, University College London, London, UK. $\mathrm{UK}$.

${ }^{2}$ Department of Earth Sciences, University College London, London,

${ }^{3}$ School of Earth and Ocean Sciences, Cardiff University, Cardiff, UK.

${ }^{4}$ Department of Geology and Geophysics, Texas A\&M University, College Station, Texas, USA.

Copyright 2008 by the American Geophysical Union. 0883-8305/08/2008PA001640\$12.00
}

are similar to or greater than the volume of the present-day Antarctic ice sheet [Billups and Schrag, 2003; Coxall et al., 2005; Katz et al., 2008; Lear et al., 2004, 2008; Miller et al., 2008; Pekar et al., 2002].

[3] Following Pearson et al. [2008] we use "EoceneOligocene transition" (EOT) to denote the extended interval of climatic and biotic change lasting about $500 \mathrm{ka}$ between 33.5 and $34.0 \mathrm{Ma}$, which spans both the $\mathrm{E} / \mathrm{O}$ boundary $(\mathrm{EOB})$ at $33.7 \mathrm{Ma}$ and the positive $\delta^{18} \mathrm{O}$ shift. Recent highresolution records of the EOT have identified two distinct $\sim 40 \mathrm{ka}$ steps within the $\delta^{18} \mathrm{O}$ shift, termed here step 1 and step 2, which are separated by a $\sim 200$ ka plateau [Coxall et al., 2005]. Step 1 and the plateau occur in the uppermost part of magnetochron $\mathrm{C} 13 \mathrm{r}$, while the maximum positive $\delta^{18} \mathrm{O}$ values at the end of step 2 directly correlate with the base of chron $\mathrm{C} 13 \mathrm{n}$ and mark the end of the EOT and the start of the $\sim 400$ ka Early Oligocene Glacial Maximum (EOGM) [Coxall and Pearson, 2007; Coxall et al., 2005; Liu et al., 2004; Zachos et al., 1996]. The major ocean-wide increase in $\delta^{13} \mathrm{C}$, which appears to lag the shift in $\delta^{18} \mathrm{O}$ by $\sim 10 \mathrm{ka}$ [Coxall et al., 2005], is compelling evidence for a significant perturbation in the global carbon cycle through the EOT [Merico et al., 2008; Salamy and Zachos, 1999; Zachos and Kump, 2005; Zachos et al., 1996]. This positive shift in $\delta^{13} \mathrm{C}$ is indicative of either an increase in the removal rate of light carbon from the ocean-atmosphere system, which has been attributed to the enhanced burial of organic carbon in marine sediments coupled to increased surface water productivity [Diester-Haass and Zachos, 2003; Salamy and Zachos, 1999; Zachos and Kump, 2005] or the input of isotopically heavy carbon via the increased weathering of neritic carbonates during a major 
sea level fall [Merico et al., 2008]. Both of these hypotheses are associated with a drawdown of atmospheric carbon dioxide that may be the principal positive feedback mechanism that drove the climate system into a strongly glaciated state during the EOGM [Merico et al., 2008; Zachos and Kump, 2005].

[4] Evidence for significant increases in primary production through the EOT has been documented at a number of deep-sea sites in the Southern Ocean [Anderson and Delaney, 2005; Diester-Haass et al., 1996; Latimer and Filippelli, 2002; Salamy and Zachos, 1999], probably driven by cooling induced increases in surface-ocean divergence and the associated upwelling of nutrient-rich deep waters and/or enhanced fluxes of weathering derived nutrients during rapid sea level fall [Nilsen et al., 2003; Salamy and Zachos, 1999; Zachos and Kump, 2005]. There is however a lack of comparable paleoproductivity records from the low latitudes [but see Diester-Haass and Zachos, 2003; Nilsen et al., 2003; Ravizza and Paquay, 2008] where quantifying changes in primary carbonate and silica fluxes at many deep-sea sites is hampered by the dramatic deepening of the carbonate compensation depth (CCD) and the associated shift from siliceous to calcareous sediments through the EOT [Nilsen et al., 2003].

[5] Studies of modern coccolithophores (calcareous scaleproducing haptophyte algae) have shown that the species makeup and community structure of assemblages are highly sensitive to surface water stratification, nutrient availability and nutricline depth. In the modern oceans there is a general correlation between high-productivity environments and low-diversity coccolithophore assemblages, dominated by bloom-forming species such as Emiliania huxleyi, while oligotrophic environments are associated with diverse assemblages, often with a clear depth zonation and a distinct lower photic zone (LPZ) flora [Broerse et al., 2000; Kinkel et al., 2000; McIntyre and Bé, 1967; Okada and Honjo, 1973]. The response of the calcareous phytoplankton to global change through the Eocene-Oligocene boundary is poorly known when compared to other critical intervals such as the Paleocene-Eocene boundary [e.g., Bralower, 2002; Gibbs et al., 2006a, 2006b; Raffi et al., 2005]. One set of high-resolution records from the Southern Ocean has shown a significant fall in nannofossil diversity and an increase in cold water taxa directly coincident with the onset of the EOGM [Persico and Villa, 2004] but there is no comparable data set from the low latitudes, with previous quantitative records being either at low resolution $(\sim 100 \mathrm{ka})$ [Wei et al., 1992; Wei and Wise, 1990] or severely compromised by poor preservation [Coccioni et al., 1988; Monechi, 1986].

[6] The recent recovery of a latest Eocene to earliest Oligocene sequence of hemipelagic clays from coastal Tanzania [Nicholas et al., 2006], which host exceptionally well preserved calcareous microfossils [Bown et al., 2008a; Pearson et al., 2008], provides a unique opportunity to examine the coccolithophore response through this critical climatic transition in a low-latitude setting. In this study we present a high-resolution record of coccolithophore assemblages through this succession and discuss their implications for changes in surface water productivity linked to major climate change. The deposition of these sediments in an outer shelf to upper slope environment, well above the paleolysocline, means they were unaffected by the dramatic variations in CCD depth through the EOT. Samples taken across the EOT consistently yield a highly diverse and exceptionally well preserved calcareous nannofossil assemblage (Figure 1) [Bown et al., 2008a; Dunkley Jones et al., 2008] and can be correlated directly to the EoceneOligocene boundary by planktonic foraminifera biostratigraphy [Wade and Pearson, 2008] and the onset of the EOGM by stable isotope stratigraphy [Pearson et al., 2008].

\section{Materials and Methods}

[7] This study is part of an ongoing paleoclimate research project, the Tanzanian Drilling Project (TDP), which is focused on recovering geochemical and paleobiological data using exceptionally well preserved calcareous microfossils from the Cretaceous and Paleogene sediments of the Kilwa Group, coastal Tanzania [Pearson et al., 2001, 2007, 2008]. The two cores examined in this study, TDP12 $\left(9^{\circ} 12^{\prime}\right.$ $54.74 "$ S $39^{\circ} 32^{\prime} 53.60^{\prime \prime}$ E; total depth $\left.147.44 \mathrm{~m}\right)$ and TDP17 $\left(9^{\circ} 11^{\prime} 11.38 "\right.$ S $39^{\circ} 33^{\prime} 3.822^{\prime \prime} \mathrm{E}$; total depth $125.9 \mathrm{~m}$ ) overlap to provide a continuous stratigraphic sequence across the EOT; both sites were located on the Pande Peninsula, approximately $3 \mathrm{~km}$ apart, in the Kilwa Administrative District, Tanzania (Figure 2). The cores are composed of a succession of dark greenish-gray clays with occasional limestone interbeds, typical of the middle Eocene to lower Oligocene Pande Formation [Nicholas et al., 2006], and span the EOB, nannofossil zones NP19/20 and 21 [Martini, 1971] and planktonic foraminifera zones E15/ E16 and O1 [Berggren and Pearson, 2005].

[8] The in situ benthic foraminiferal assemblage of the Pande clays, recovered in TDP12 and TDP17, consists of "flysch"-style agglutinated forms, dominated by Bathysiphon, and a deep water calcareous fauna typical of outer shelf to upper slope environments (300-500 m water depth) [Nicholas et al., 2006]. Abundant allocthonous microscopic shell debris, transported from the innermost shelf, is present throughout the succession and often dominates benthic foraminiferal assemblages. The consistent presence of the specialist lower photic zone calcareous phytoplankton genera Gladiolithus and Algirosphaera (Figures $1 \mathrm{i}$ and $1 \mathrm{j}$ ) within the studied sections, constrains the setting to a relatively deep, clear water environment [Jordan and Chamberlain, 1997; Takahashi and Okada, 2000].

[9] The TDP12 and TDP17 successions were correlated using planktonic (last occurrences of the Hantkeninidae and Turborotalia cerroazulensis group) and benthic foraminiferal (late Eocene last occurrence of a characteristic but undescribed Migros sp.) and calcareous nannofossil (last occurrence of Pemma papillatum) bioevents. The age model for the two sites is based upon bioevents using the age assignments of Berggren et al. [1995] with additional control provided by tuning the composite TDP12 and TDP 17 planktonic foraminifera (Turborotalia ampliapertura) oxygen isotope $\left(\delta^{18} \mathrm{O}\right)$ record to the deep sea benthic foraminiferal (Cibicidoides) $\delta^{18} \mathrm{O}$ record from 


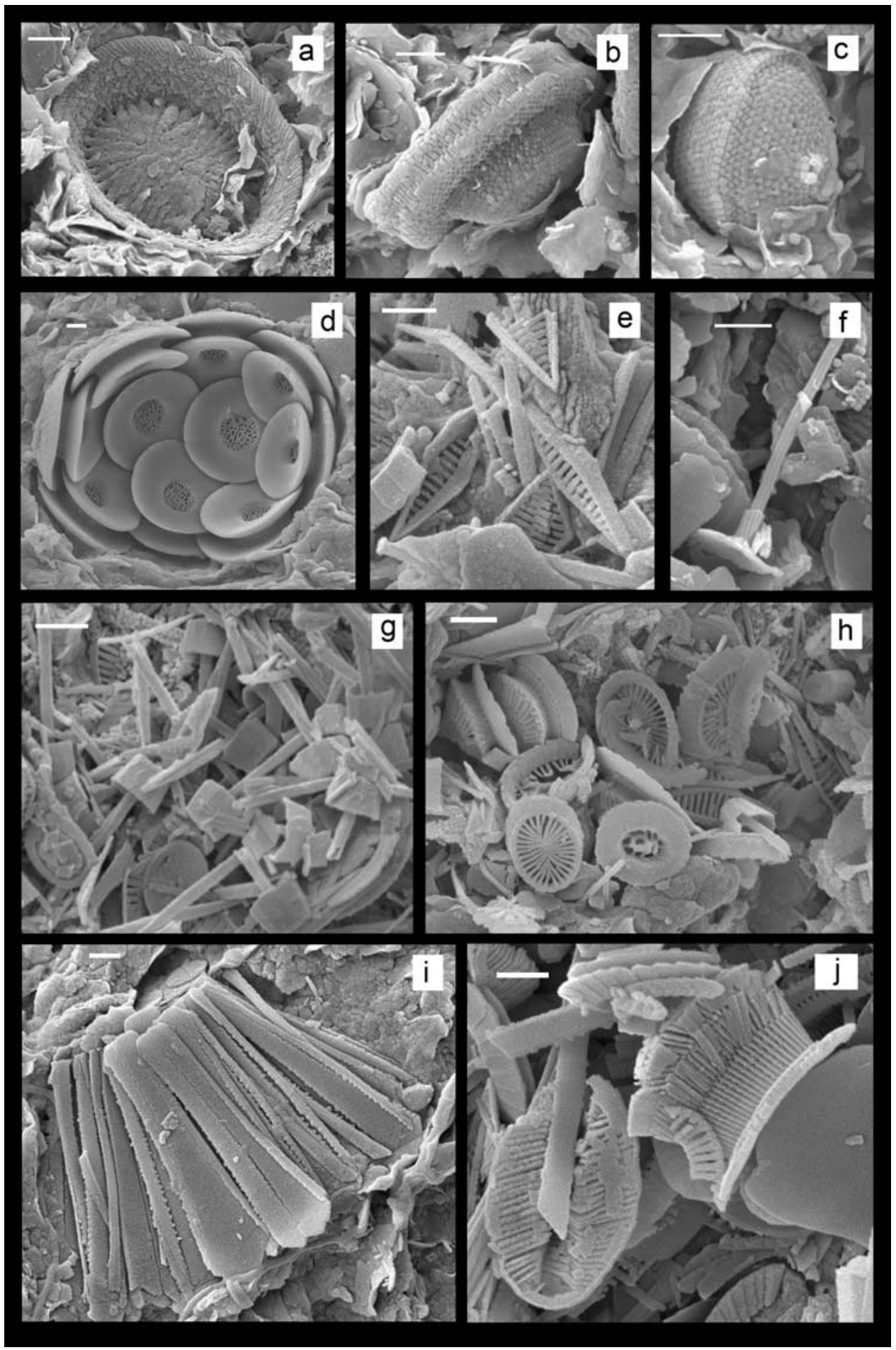

Figure 1. Scanning electron microscope images of selected calcareous nannofossils, all scale bars are $1 \mu \mathrm{m}$ : (a) Pontosphaera versa TDP12/23-2, $79 \mathrm{~cm}$; (b) Orthozygus sp. (holococcolith) TDP12/42-3, $86 \mathrm{~cm}$; (c) Varolia cistula (holococcolith) TDP12/47-2, $64 \mathrm{~cm}$; (d) Cyclicargolithus floridanus partcoccosphere TDP12/26-2, $62 \mathrm{~cm}$; (e) Calciosolenia sp. TDP12/26-2, $62 \mathrm{~cm}$; (f) Rhabdosphaera sp. TDP12/47-2, $64 \mathrm{~cm}$; (g) small spinose murolith TDP12/26-2, $62 \mathrm{~cm}$; (h) Syracosphaera sp. and Blackites sp. TDP12/26-2, $62 \mathrm{~cm}$; (i) Gladiolithus flabellatus part coccosphere TDP12/26-2, $62 \mathrm{~cm}$; and (j) Algirosphaera sp. TDP12/26-2, $62 \mathrm{~cm}$. 


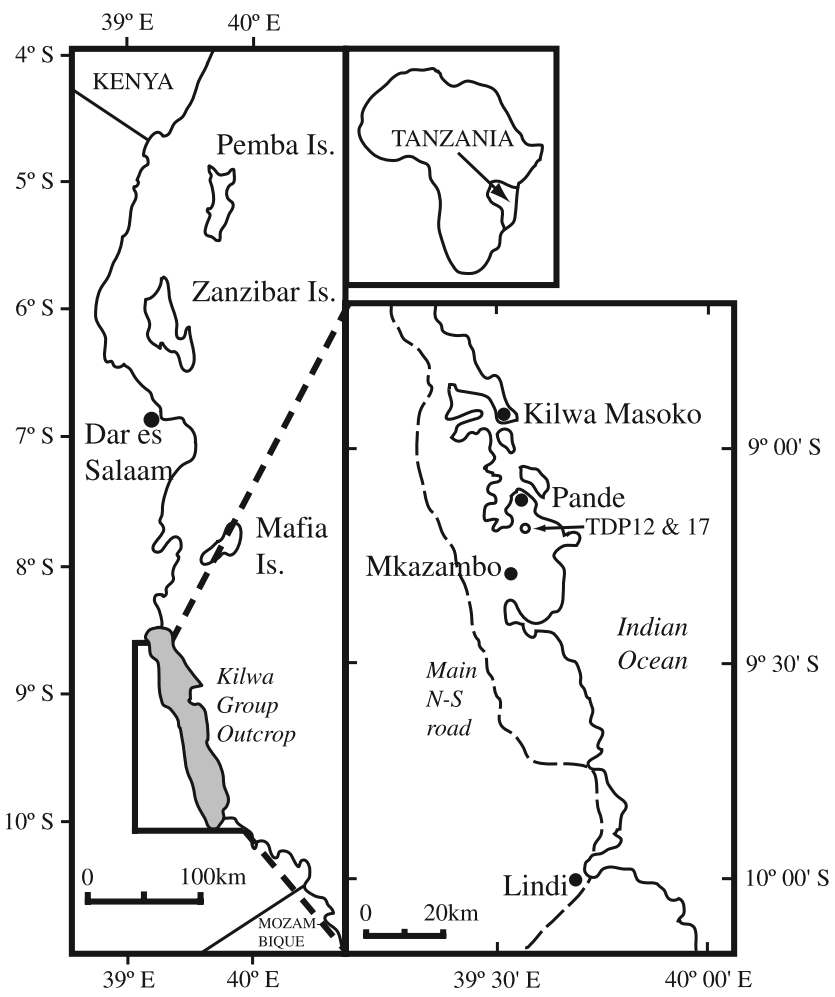

Figure 2. Location map for the TDP Site 12 and TDP Site 17 boreholes.

equatorial Pacific ODP Site 1218 [see Pearson et al., 2008]. All depths are in meters composite depth (mcd) unless otherwise stated. The last occurrence of Discoaster saipanensis (NP19-20/21 nannofossil zone boundary) at 130.35 mcd appears to be slightly high in the succession when compared to ages based on the correlation of stable isotope curves between these sites and ODP Site 1218. There are difficulties in placing this event as D. saipanensis is present at very low abundances in this material and may be subject to reworking, as a result this datum was not used within the age model. The base of planktonic foraminifera zones E15 and E16 are undifferentiated because of the absence of Globigerinatheka index in these sections as discussed by Wade and Pearson [2008].

[10] Sediment samples, approximately $2 \mathrm{~cm}^{3}$ in volume, were extracted at $\sim 1 \mathrm{~m}$ intervals and thoroughly scraped clean. Simple smear slides were made, taking care to maintain a consistent density of diluted sediment, using a small quantity of sediment and distilled/deionized water. This approach is the most suitable for the analysis of these diverse assemblages, which include a significant number of fragile taxa, as it minimizes the amount of sample processing and the associated risks of nannofossil fragmentation and dissolution. Duplicate smear slides from TDP12 indicate that transport and storage of samples did not have a deleterious effect on nannofossil preservation and that diversity measures are reproducible [Dunkley Jones and Bown, 2007]. All of the clay samples appeared homogeneous on the millimeter scale with no sign of laminations.
[11] A total of 107 slides were examined for calcareous nannofossils from TDP12 (range in original depth scale 147.8 to $18.69 \mathrm{~m}$ below ground level (mbgl)), and 65 slides from TDP17 (range in original depth scale 101.11 to $31.15 \mathrm{mbgl}$ ), using standard light microscope techniques at a magnification of $1250 \mathrm{x}$ on an Olympus BX40 microscope. Up to 20 consecutive fields of view (FOV) were initially examined for each slide, with all whole identifiable nannofossil specimens counted. Specimens were identified to species level wherever possible, following the taxonomy of Dunkley Jones et al. [2008]. During this count, the number of whole reworked Cretaceous nannofossils and the number of cubic pyrite grains were counted per FOV. Counts were terminated when at least 400 complete in situ identifiable nannofossils had been counted; where necessary, counts were extended beyond $20 \mathrm{FOV}$, along continuous transects, until at least 400 specimens had been counted. Occasional samples from both boreholes contained very low nannofossil abundances ( $\sim 4$ or less per FOV); these were examined and counted as normal for 20 FOV to obtain nannofossil abundance, Cretaceous reworking and mineralogical counts but were then abandoned. Samples and slides are curated at the Department of Earth Sciences, University College London. The surfaces of broken rock chips were examined using a JEOL Digital JSM-6480LV scanning electron microscope, following the methodology of Lees et al. [2004]. A large number of new and novel taxa were encountered during this work (Figure 1) and these are described in a separate taxonomic study [Dunkley Jones et al., 2008].

[12] Metric Multidimensional Scaling (MMDS) was performed on a reduced set of relative abundance data, for a total of 29 species, with the exclusion of species whose standard deviation of their relative abundances was less than $0.5 \%$, followed by the rescaling of the data to sum to $100 \%$. This eliminates rarely occurring species, with relative abundances typically less than $1 \%$, and follows the standard procedure for the multivariate analysis of subcomposition data [Pawlowsky-Glahn and Egozcue, 2006]. Before analysis, zero data were replaced using the rounded zero replacement routine of the CoDaPack multivariate data analysis software [Thió-Henestrosa and Martín-Fernández, 2006] and then additive-log-ratio (ALR) transformed, with the most dominant species, the small form of Cyclicargolithus floridanus $(<5 \mu \mathrm{m})$, used as the denominator. This allows the use of standard multivariate methods on percentage compositional data, although the denominator variable, Cyclicargolithus floridanus $(<5 \mu \mathrm{m})$, is not present in the transformed data set [Pawlowsky-Glahn and Egozcue, 2006]. The transformed data were standardized before running the MMDS, which used the Euclidean distance measure to obtain a dissimilarity matrix between the multidimensional data and squared stress as the goodness-of-fit criterion between the multidimensional and two-dimensional distances. This method produces a two-dimensional representation of the samples that seeks to preserve and represent the distances between samples in the multidimensional space defined by the variables analyzed, in this 
case, species abundances. MMDS was performed in MATLAB, using the standard statistics toolbox.

\section{Results}

[13] The planktonic foraminiferal (Turborotalia ampliapertura) stable isotope record [Pearson et al., 2008] is similar in structure to the most complete benthic foraminifera isotope records from the deep sea [Coxall et al., 2005; Zachos et al., 1996], with a $\sim 1$ per mil increase in oxygen isotopes occurring over two steps into the most positive isotope values of the EOGM (Figure $3 \mathrm{a}$ ). The T. ampliapertura $\mathrm{Mg} / \mathrm{Ca}$ record, converted into a SST estimate [Lear et al., 2008] shows a marked cooling of $\sim 2{ }^{\circ} \mathrm{C}$ at $\sim 33.9 \mathrm{Ma}$, just before the onset of the first step in oxygen isotopes at $\sim 33.8 \mathrm{Ma}$; interpolating between this $\mathrm{Mg} / \mathrm{Ca}$ data and the oxygen isotope data it is possible to reconstruct an estimated pattern of near-surface water $\delta^{18} \mathrm{O}_{\mathrm{SW}}$ (Figure 3a), which shows a slight increase over step 1 followed by a marked increase across step 2 [Lear et al., 2008].

[14] In the uppermost Eocene, before $\sim 34.0 \mathrm{Ma}$, nannofossil abundance is variable but high, normally ranging between 500 and 1500 specimens $/ \mathrm{mm}^{2}$ (Figure 3b). Just prior to step $1(\sim 34.0-33.8 \mathrm{Ma})$, however, there are a number of distinctly low-abundance to almost barren intervals before abundances recover within step 1. Abundances remain moderately high through the EOB and step 2 but decline to consistently lower values $\left(\sim 500\right.$ specimens $\left./ \mathrm{mm}^{2}\right)$ toward the end of the EOGM at $\sim 33.3 \mathrm{Ma}$. In contrast to the relatively stable values of species richness throughout the section, there is a marked discontinuity in Shannon diversity immediately above the EOB $(\sim 33.63 \mathrm{Ma})$, which separates relatively high values in the late Eocene (mean 2.67) from the significantly lower values of the earliest Oligocene (mean of 2.41 between 33.63 and $33.1 \mathrm{Ma}$ ) (Figure 3b). Counts of cubic pyrite abundance, which is broadly associated with the organic carbon content of sediments [Goldharber, 2004], are relatively stable within the uppermost Eocene sediments but then show a number of distinct spikes above $\sim 33.9 \mathrm{Ma}$, which continue through the oxygen isotope shift and into the base of the EOGM. Likewise, significant levels of reworked Cretaceous nannofossils, predominantly Campanian-Maastrichtian taxa, suddenly appear in the sediments at $\sim 33.97 \mathrm{Ma}$ (mean values below and above this level 3.8 and 44 specimens $/ \mathrm{mm}^{2}$ respectively) and continue to be variably present up into the lower Oligocene, reaching peak values just above step 2 .

[15] The small form of Cyclicargolithus floridanus $(<5 \mu \mathrm{m})$, is the dominant species throughout the succession but shows an increased abundance across the EOB (mean Eocene value of 27.7\%; Oligocene mean 41.3\%) (Figure 4a). Likewise the larger form of Cyclicargolithus floridanus $(>5 \mu \mathrm{m})$ and Sphenolithus predistentus also show a clear increase in relative abundance across the EOB (mean Eocene values of 1.3 and $0.9 \%$ respectively; Oligocene means 9.7 and 5.9\%). Reticulofenestra sp. A (small with wide central area described by Dunkley Jones et al. [2008]) shows low abundances in the Eocene (mean 1.1\%) but increases in abundance in the Oligocene (mean 2.6\%) (Figure 4a).
[16] A number of taxa show a clear trend of decreased relative abundance between the latest Eocene and early Oligocene, with many of them not present or rarely occurring above the EOB (Figures $4 \mathrm{~b}$ and 5a). Calcidiscus protoannulus and Lanternithus minutus are the most abundant of this group, with mean abundances, in the Eocene of 12.7 to $7.6 \%$ respectively, which drop to 0.4 and $0.5 \%$ in the Oligocene. The notable difference between the records of these two species is their behavior around the EOB; the relative abundance of Calcidiscus protoannulus continues a declining trend from the latest Eocene through the EOB into the earliest Oligocene, whereas the relative abundance of Lanternithus minutus peaks to an abundance of $14.9 \%$ in the sample immediately below the EOB. Other species that show similar trends include Reticulofenestra dictyoda and two holococcolith taxa, Varolia macleodii and Zygrhablithus bijugatus, which all have low but consistent relative abundances in the Eocene, typically $2-5 \%$, but decline to rare occurrences in the Oligocene, and Pemma papillatum, which has a distinct last occurrence $\sim 100 \mathrm{ka}$ before the EOB at $\sim 33.8 \mathrm{Ma}$. The mean abundances of total Discoaster spp. decrease across the EOB, relative to their general low abundance, with an Eocene value of $1.1 \%$ and an Oligocene value of $0.2 \%$ (Figure $4 b$ ). Holococcolith taxa make up a considerable proportion of the late Eocene nannofossil assemblages (Figure 5a) but there is a marked decline in total holococcolith abundance at both $\sim 34.2 \mathrm{Ma}$ and then more significantly at the EOB. Mean holococcolith relative abundances for the Eocene and Oligocene are $12.9 \%$ and $2.8 \%$ respectively.

[17] The three species Reticulofenestra minuta, Coccolithus pelagicus and Sphenolithus moriformis all have consistent moderate to low abundances ( $\sim 2$ to $10 \%$ ) throughout TDP12 and TDP17 (Figure 5b), although Reticulofenestra minuta does show a slight abundance decline into the Oligocene. The incertae sedis nannolith Pemma? triquetra is abundant throughout the section but new detailed SEM imaging of this taxon strongly suggests that this is a disaggregated pentalith of the family Braarudosphaeraceae [Dunkley Jones et al., 2008], in which case its abundance is inflated fivefold and if rescaled would be more comparable to other minor assemblage components at $\sim 2-3 \%$.

[18] On the basis of broadly increasing or declining relative abundances, two species groups can be defined. Group 1 consists of species with declining abundances across the EOB: Calcidiscus protoannulus, Reticulofenestra dictyoda, Pemma papillatum, Lanternithus minutus, Varolia macleodii and Zygrhablithus bijugatus. Group 2 consists of Sphenolithus predistentus and the large form of Cyclicargolithus floridanus, which both increase in abundance across the EOB. These plots of grouped relative abundances (Figure 6b) more clearly illustrate the dominant trends and major changes in assemblage composition by minimizing small-scale fluctuations in individual species data. The total relative abundance plot for group 1 species shows the marked transition across the EOB, from high abundances in the Eocene (mean 25.6\%) to low values in the Oligocene (mean 1.2\%). Conversely group 2 species have a low grouped relative abundance in the late Eocene 

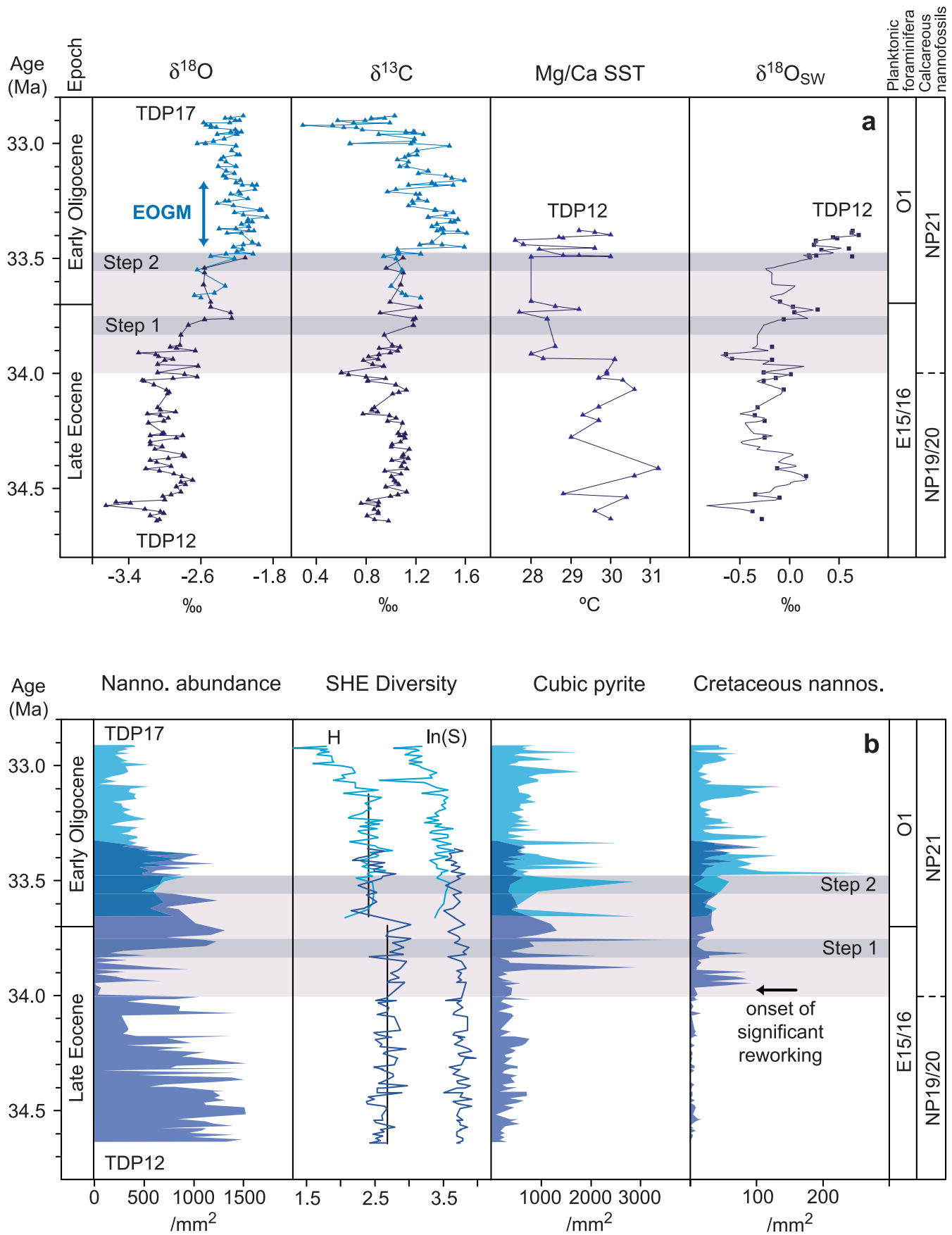

Figure 3. Geochemical and smear slide count data across the Eocene-Oligocene transition. (a) Stable isotopes $\left(\delta^{18} \mathrm{O}\right.$ and $\left.\delta^{13} \mathrm{C}\right)$ [Pearson et al., 2008] and $\mathrm{Mg} / \mathrm{Ca}$ ratios [Lear et al., 2008] from planktonic foraminifera Turborotalia ampliapertura and calculated near-surface $\delta^{18} \mathrm{O}_{\mathrm{SW}}$ [Lear et al., 2008]. (b) Nannofossil abundance, SHE diversity (Shannon's H, left-hand curve, and ln (S), right-hand curve), and abundance of cubic pyrite and reworked Cretaceous nannofossils. Data are from TDP Site 12 (base of section, purple) and TDP Site 17 (top of section, light blue). The horizontal gray bars indicate the duration of the globally recognized first and second positive steps in $\delta^{18} \mathrm{O}$, the pink shading indicates the duration of the EOT (34.0-33.5 Ma), and the position of the Early Oligocene Glacial Maximum (EOGM) is marked on the plot of $\delta^{18} \mathrm{O}$. Planktonic foraminifera biozones of Berggren and Pearson [2005] and calcareous nannofossil biozones of Martini [1971] are marked on the right-hand side; there is some uncertainty in the placement of the NP19/20-21 nannofossil zone boundary. 

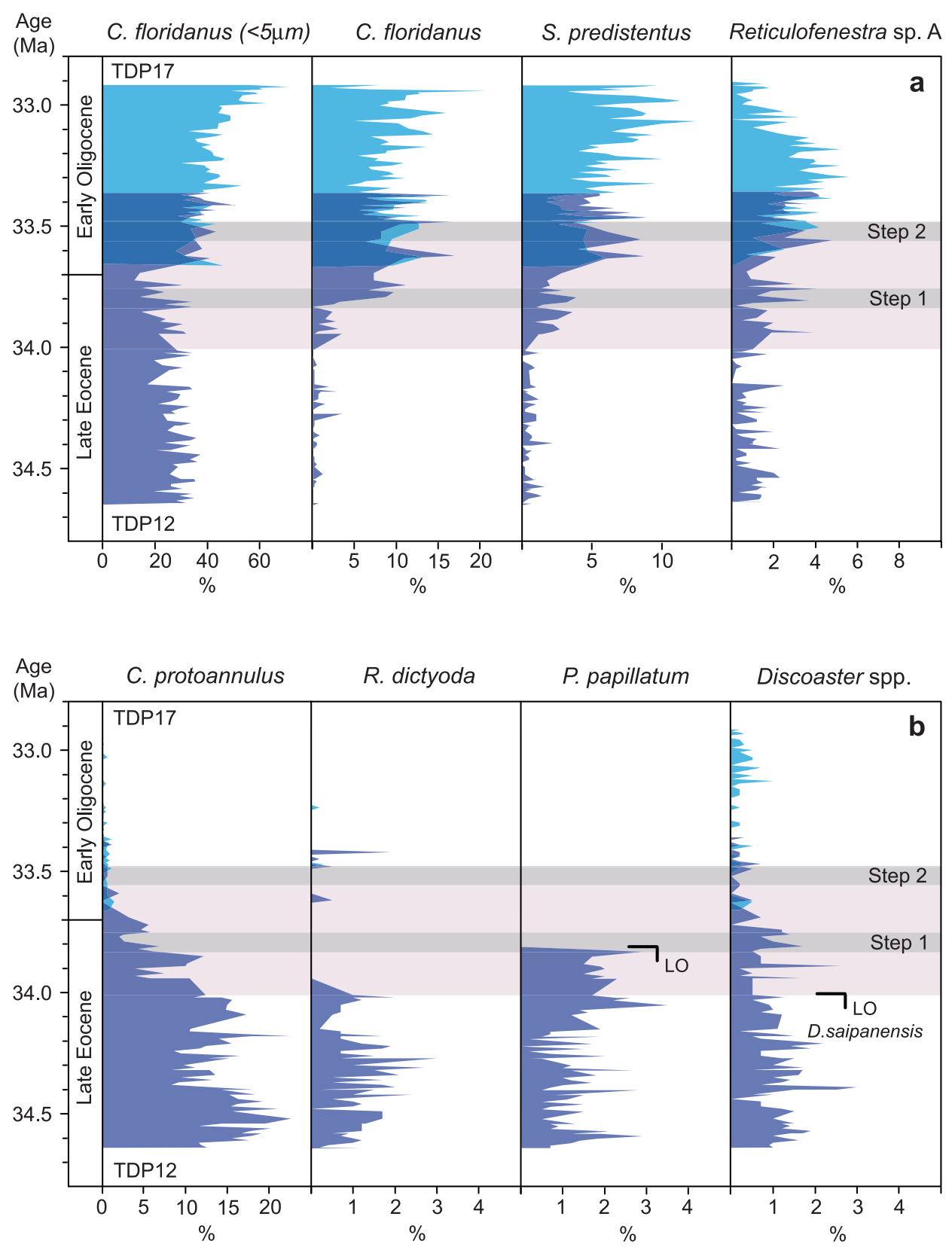

Figure 4. Nannofossil species relative abundance data across the Eocene-Oligocene transition. (a) From left to right, Cyclicargolithus floridanus $(<5 \mu \mathrm{m})$, Cyclicargolithus floridanus, Sphenolithus predistentus, and Reticulofenestra sp. A. (b) From left to right, Calcidiscus protoannulus, Reticulofenestra dictyoda, Pemma papillatum, and grouped Discoaster spp.; last occurrences of P. papillatum and D. saipanensis are marked. Data are from TDP Site 12 (base of section, purple) and TDP Site 17 (top of section, light blue). The horizontal gray bars indicate the duration of the globally recognized first and second positive steps in $\delta^{18} \mathrm{O}$, and the pink shading indicates the duration of the EOT (34.0-33.5 Ma).

(mean $1.4 \%$ below $33.8 \mathrm{Ma}$ ) but this increases dramatically at the onset of step $1(\sim 33.8 \mathrm{Ma})$ and into the Oligocene (mean $15.2 \%$ above $33.8 \mathrm{Ma}$ ).

[19] The first two coordinates of the Metric Multidimensional Scaling (MMDS1 and MMDS2) analysis represent the major components of variation within the multivariate (species relative abundance) space, in a fashion similar to the first two components of a principal component analysis (Figure 6a). Two principal clusters of samples are clearly resolved: Eocene samples older than 34.0 Ma ("Eocene") with generally negative values of MMDS1 and Oligocene samples with positive values. Samples between $\sim 34.0 \mathrm{Ma}$ and the EOB, labeled "Transitional", plot with intermediate MMDS1 values and high positive values of MMDS2. A plot of MMDS1 against age clearly resolves the pattern of nannofossil assemblage changes through time (Figure 6b), namely relative stability below $\sim 34.0 \mathrm{Ma}$, a first transition (T1) to higher values between $\sim 34.0 \mathrm{Ma}$ and the EOB, and 

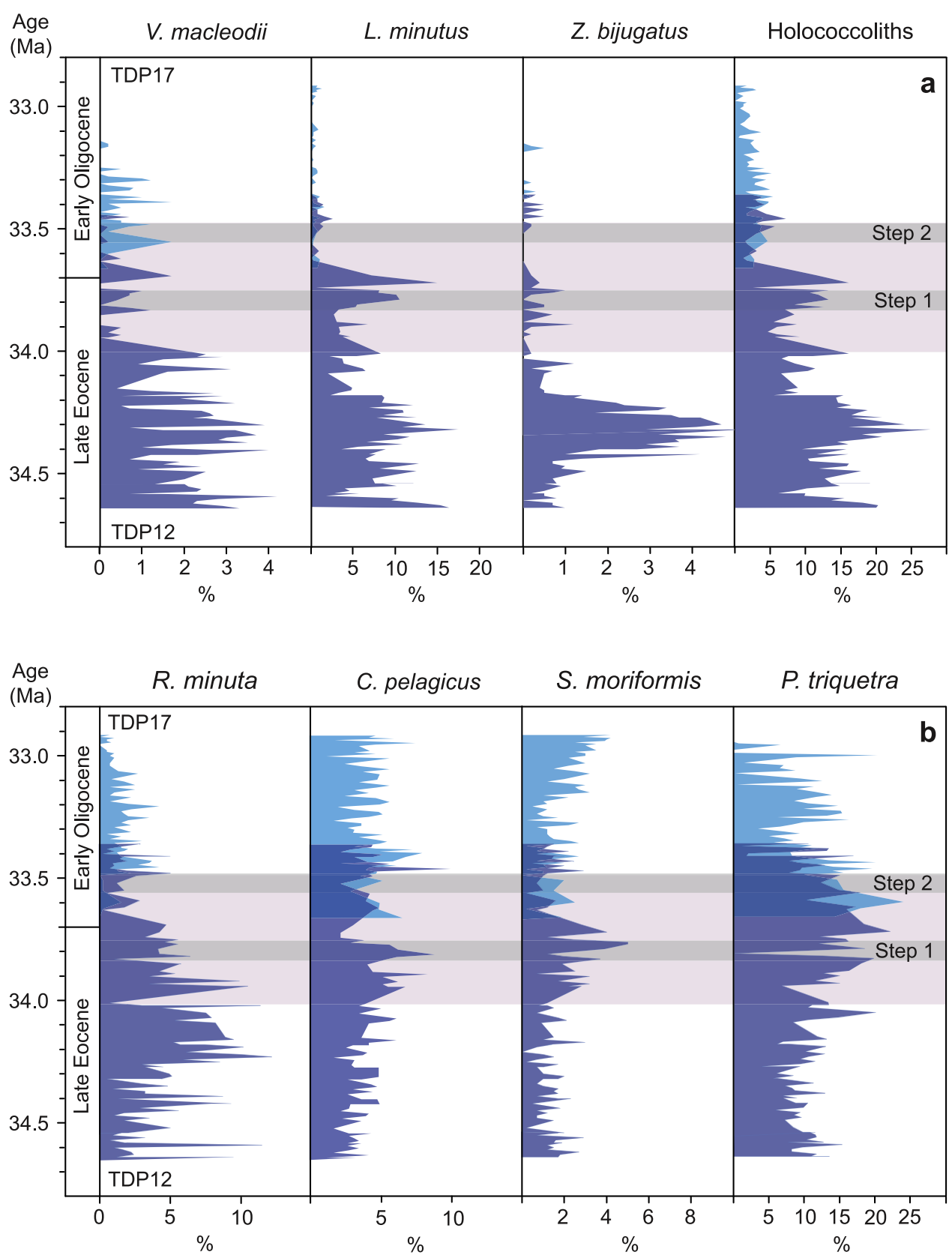

Figure 5. Nannofossil species relative abundance data across the Eocene-Oligocene transition. (a) From left to right, three holococcoliths species, Varolia macleodii, Lanternithus minutus, and Zygrhablithus bijugatus, and total holococcolith abundance. (b) From left to right, Reticulofenestra minuta, Coccolithus pelagicus, Sphenolithus moriformis, and Pemma? triquetra. Data are from TDP Site 12 (base of section, purple) and TDP Site 17 (top of section, light blue). The horizontal gray bars indicate the duration of the globally recognized first and second positive steps in $\delta^{18} \mathrm{O}$, and the pink shading indicates the duration of the EOT (34.0-33.5 Ma).

a second transition (T2) just above the EOB $(\sim 33.63 \mathrm{Ma})$ to the high positive values of the Oligocene.

\section{Discussion}

[20] This discussion focuses on three key issues: the timing of major transitions in the nannofossil record, the nature of nannofossil assemblage changes and the potential paleoceanographic and climatic controls on these shifts.

\subsection{Timing of Events Through the EOT}

[21] The variation in $\mathrm{H}$ diversity (Figure 3b), the first coordinate of the multidimensional scaling analysis (MMDS1) and the relative abundance plots of group 1 and 2 species (Figure 6b) summarize the major changes in 

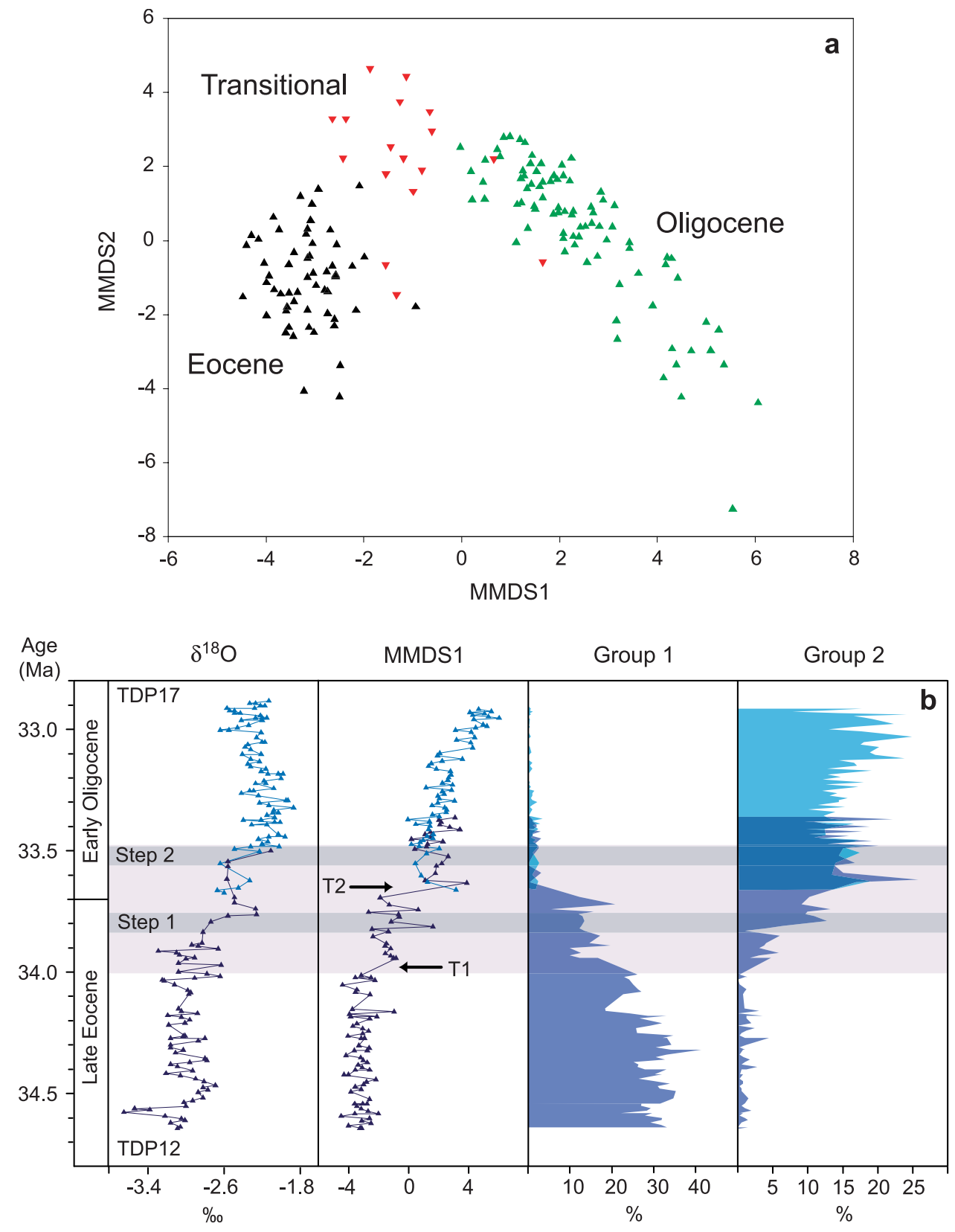

Figure 6. Results of the multivariate analysis of nannofossil assemblages. (a) First and second coordinates (MMDS1 and MMDS2) of the Metric Multidimensional Scaling, samples divided into "Eocene" (before 34.0 Ma), "Transitional" (34.0 Ma to 33.7 Ma) and "Oligocene" (after 33.7 Ma) groups. (b) From left to right, Turborotalia ampliapertura $\delta^{18} \mathrm{O}$ [Pearson et al., 2008], first coordinate of the Metric Multidimensional Scaling analysis plotted against age (MMDS1), and grouped nannofossil abundance data (group 1, Calcidiscus protoannulus, Reticulofenestra dictyoda, Pemma papillatum, Lanternithus minutus, Varolia macleodii, and Zygrhablithus bijugatus; group 2, Sphenolithus predistentus and the large form of Cyclicargolithus floridanus). First (T1; 34.0 Ma) and second (T2; $\sim 33.63 \mathrm{Ma}$ ) major transitions in nannofossil assemblages are indicated on the plot of MMDS1. Data are from TDP Site 12 (base of section, purple) and TDP Site 17 (top of section, light blue). The horizontal gray bars indicate the duration of the globally recognized first and second positive steps in $\delta^{18} \mathrm{O}$, and the pink shading indicates the duration of the EOT (34.0-33.5 Ma). 
nannofossil assemblages through the EOT. The older, late Eocene part of this succession, below $\sim 34.1 \mathrm{Ma}$, has stable nannofossil assemblages, as shown by the relatively constant $\mathrm{H}$ diversity, MMDS1 and group 1 and 2 abundances (Figures $3 \mathrm{~b}$ and $6 \mathrm{~b}$ ). This is paralleled by relatively steady T. ampliapertura $\delta^{18} \mathrm{O}$ values (Figure 3a). The first disruption to this stability (T1) occurs across an interval of very low nannofossil abundances between $\sim 34.0-33.95 \mathrm{Ma}$ (four successive samples between 129.84 and $124.39 \mathrm{mcd}$ in TDP12), which is coincident with a negative peak in $\delta^{13} \mathrm{C}$, the onset of the first significant abundances of reworked Cretaceous nannofossils $(\sim 33.96 \mathrm{Ma}$; $125.56 \mathrm{mcd})$ and $\mathrm{a} \sim 2{ }^{\circ} \mathrm{C}$ cooling of SSTs recorded by T. ampliapertura $\mathrm{Mg} / \mathrm{Ca}$ ratios ( 33.94 Ma: $122.4 \mathrm{mcd}$ ). This pronounced interval of low nannofossil abundances may be due to dissolution, either in the water column or during sediment diagenesis, dilution by other sedimentary constituents or low nannofossil productivity. Dissolution is unlikely, first because rare but well-preserved late Eocene nannofossils are still preserved within these sediments and second this is a relatively shallow (300-500 m paleowater depth) location significantly above the lysocline. Dilution of the nannofossil component is possible but would require a large change in sedimentation rates to account for the $\sim 50$ to 100 fold decrease in nannofossil abundance throughout this $5 \mathrm{~m}$ interval, in which there is no discernable change in the clay-rich lithology. The third possibility is an ecological event could account for both a decline in calcareous phytoplankton primary production and the observed transition (T1) in nannofossil assemblages. A fall in carbonate productivity, if widespread across the low-latitude oceans, could directly explain the negative trending $\delta^{13} \mathrm{C}$ values and the transient shoaling of the CCD observed immediately prior to the first $\delta^{18} \mathrm{O}$ step [Coxall et al., 2005] and may be coupled, via a weakened carbonate counter pump, to a transient decline in atmospheric $\mathrm{pCO}_{2}$ and the SST cooling indicated by $\mathrm{Mg} / \mathrm{Ca}$ data.

[22] The second, and more significant, assemblage transition (T2) occurs within the $\sim 70 \mathrm{ka}$ interval immediately above the EOB within the intermediate plateau in $\delta^{18} \mathrm{O}$. This involves an abrupt and permanent reduction in the $\mathrm{H}$ diversity of the nannofossil assemblages and a major shift in the taxonomic composition of assemblages, which is clearly seen in MMDS1 and group 1 and 2 abundances (Figure 6b). In contrast to $\mathrm{T} 1$ this transition is marked by high nannofossil abundances and does not correspond with any geochemical (stable isotopes or $\mathrm{Mg} / \mathrm{Ca}$ ) or sedimentological (Cretaceous reworking or pyrite abundance) signal. The T2 nannofossil event does, however, correspond with a wider biotic response across this relatively short $\sim 70 \mathrm{ka}$ interval, involving the extinction of five species of planktonic foraminifera and dwarfing of Pseudohastigerina [Wade and Pearson, 2008] and an overturn in larger benthic foraminifera [Pearson et al., 2008]. This largely biotic event precedes the $\delta^{18} \mathrm{O}$ maximum at the start of the EOGM by $\sim 150-200 \mathrm{ka}$.

\subsection{Nannofossil Assemblages and Paleoproductivity}

[23] A large component of the nannofossil assemblage shift across the EOT consists of a marked abundance decline across all the dominant late Eocene holococcolith species (Figure 5a). The production of fragile holococcoliths, formed of $\sim 0.1 \mu \mathrm{m}$ equidimensional calcite crystallites (Figures 1a and 1b), during the haploid phase of the coccolithophore life cycle, and more robust heterococcoliths (e.g., the placoliths of Figure 1d) during the diploid phase, has only recently been established [Billard, 1994; Young et al., 1999] and understanding the environmental trigger and adaptive function of the holococcolith-heterococcolith (haploid-diploid) transition in the coccolithophores is at an early stage [Cros et al., 2000; Noël et al., 2004]. Plankton sampling of the modern oceans has, however, established an association between high holococcolith abundances, near-surface habitats and generally oligotrophic conditions [Cros et al., 2000; Kleijne, 1991; Winter et al., 1994]. In spite of the potential environmental sensitivity of holococcoliths, their use in paleoceanographic reconstructions has been minimal because of their low preservation potential. The exceptional preservation of the Tanzanian sections through the EOT provides a unique deep-time record of the response of the holococcolith-bearing phase to a major environmental perturbation. The strong decline in the relative abundance of holococcoliths through the EOT can be interpreted as a significant shift away from oligotrophic surface water conditions. This assumes that there is no systematic decline in the preservational state, which would strongly affect the record of holococcoliths, but this is unlikely as very fragile holococcolith taxa, such as Orthozygus spp., are still well preserved in the basal Oligocene, whereas the abundances of more robust forms such as Lanternithus and Zygrhablithus decline significantly.

[24] Further support for increasing productivity through the EOT is provided by the record of coccolithophore diversity. In modern coccolithophore assemblages, variations in the Shannon measure of ecological diversity $(\mathrm{H})$ are correlated to changes in the nutrient content of surface waters, with r-selected, opportunist, usually placolith-bearing species, dominant in eutrophic conditions (low $\mathrm{H}$ diversity) while a more diverse flora of k-selected species develops under nutrient-limited conditions (high $\mathrm{H}$ diversity) [Broerse et al., 2000; Jordan, 2002]. The most rapid transition in the coccolithophore assemblages in this study is immediately after the EOB and is marked by a major and rapid decline in $\mathrm{H}$ diversity from late Eocene assemblages with a mean value of 2.67 to those of the earliest Oligocene with a mean of 2.41 (Figure 3b). This change in $\mathrm{H}$ is largely due to the increased dominance of Cyclicargolithus floridanus and the loss of important subdominant taxa, such as Calcidiscus protoannulus and Lanternithus minutus. This diversity decline, coupled with the reduced abundance of oligotrophic taxa (holoccoliths and discoasters) and an increase in the abundance of the dominant, placolith-bearing species, $C$. floridanus, strongly indicates a marked increase in surface water nutrient concentrations across the EOB. This is consistent with a similar decline in the $\mathrm{H}$ diversity of planktonic foraminifera assemblages between the Eocene and Oligocene of this succession, which can also be related to more unstable and eutrophic conditions [Wade and Pearson, 2008]. 
[25] The dominance of C. floridanus (small and large forms) and Sphenolithus predistentus in the early Oligocene of Tanzania, with combined abundances of $\sim 60 \%$ or more, is similar to early Oligocene nannofossil assemblages of the equatorial Pacific Ocean, which are also dominated by C. floridanus and show increased sphenolith abundance during high-productivity intervals [Wade and Pälike, 2004]. C. foridanus has been associated with highproductivity environments [Aubry, 1992; Monechi et al., 2000], however sphenoliths have been shown to increase in abundance under both oligotrophic [Gibbs et al., 2004] and strongly eutrophic conditions [Wade and Bown, 2006]. In this study, although $S$. predistentus does show a strong increase in abundance across the EOT, the other moderately abundant sphenolith species, S. moriformis, shows no response through the same interval (Figure 5b), perhaps indicating distinct ecological adaptations within the genus.

\subsection{Paleoceanography of the EOT}

[26] What are the possible causes of the surface ocean nutrient enrichment at this location and are they indicative of wider oceanographic-climate changes at this time? It is likely that the eustatic sea level fall, coincident with the onset of major continental-scale glaciation, released a significant pulse of nutrients around continental margins through the erosion of newly exposed organic-rich shallow shelf deposits. This is supported by the onset of significant reworking of Cretaceous nannofossils from the inland Kilwa Group at $~ 33.9$ Ma. The input of freshly eroded nutrients may account for some of the enhanced productivity and nannofossil assemblage changes seen at this location, however the rapidity of the assemblage transition concentrated at the EOB and its independence from major phases of ice growth, as determined by the $\delta^{18} \mathrm{O}$ record, strongly indicate an independent biotic or physical transition in the surface water environment.

[27] An alternative explanation would be a significant switch in regional ocean circulation patterns. In low southern latitudes the present-day western boundary of the Indian Ocean is dominated by the northward flowing East African Coastal Current (EACC), which is sourced from the westward flowing South Equatorial Current (SEC) [Swallow et al., 1991]. Toward the equator the EACC begins to be influenced by monsoonal variation as it interacts with the seasonally reversing Somali Current (SC), but it is relatively stable and not associated with significant upwelling south of the equator [Schott and McCreary, 2001]. Eocene general circulation models have a similar northward flowing EACC-type current along the western boundary of the Indian Ocean, which is fed by a strong westward flowing SEC-type current between 20 and $30^{\circ} \mathrm{S}$ [Huber et al., 2004; Thomas et al., 2006]. The consistent presence of a diverse lower photic zone coccolithophore assemblage in the Kilwa Group sediments, from the late Paleocene through to the EOB [Bown et al., 2008b], indicates a long-term stable oligotrophic paleoenvironment, which is consistent with the presence of a northward flowing western boundary current through much of the Paleogene. It is unlikely that the direction of this circulation pattern altered significantly across the EOT so other mechanisms for increasing the input of nutrients into the surface ocean at this location need to be considered.

[28] Enhanced upwelling along the shelf break, driven by increased ocean-atmospheric circulation and associated turbulent mixing [Brunner and Biscaye, 2003], may have influenced this site located close to the shelf/slope transition (paleodepth $\sim 300-500 \mathrm{~m}$ ), but could not account for the more widespread disturbance of low-latitude planktonic ecosystems across the EOB. Evidence for this includes changes in equatorial Pacific radiolarian assemblages, which show a remarkably similar decline in $\mathrm{H}$ diversity and increase in cosmopolitan species abundance across the EOB [Funakawa et al., 2006] and the well-established intensive and globally synchronous extinctions within the planktonic foraminifera [Coxall and Pearson, 2007; Wade and Pearson, 2008]. One mechanism that could account for the geographical spread of this disturbance is the enhanced formation of Subantarctic Mode Water (SAMW), which in the modern ocean transports nutrients from the Subantarctic Zone to low-latitude regions of upwelling and may account for up to $75 \%$ of biological production north of $30^{\circ} \mathrm{S}$ [Sarmiento et al., 2004]. SAMW is formed by deep mixing in the Subantarctic Zone and is then transported at subthermocline depths throughout the subtropical gyres of the Southern Hemisphere [Ribbe, 2004; Sarmiento et al., 2004] and variations in the rate of formation of SAMW have been shown to connect high-latitude climate perturbations to the tropical Indian Ocean [Kiefer et al., 2006]. It is feasible that increased mixing in the Southern Ocean, coincident with Antarctic cooling and glaciation, enhanced the formation of SAMW which effectively connected southern high-latitude cooling with the tropical/subtropical oceans. New records are required to ascertain the extent of low-latitude organic carbon burial associated with these productivity increases [Ravizza and Paquay, 2008], which appears to be largely absent from the Southern Ocean [Rea and Lyle, 2005], and so test recent assertions that organic carbon burial did not play a significant role in the positive $\delta^{13} \mathrm{C}$ excursion and deepening of the CCD [Merico et al., 2008].

\section{Conclusion}

[29] The new high-resolution record of calcareous nannofossils presented here clearly shows two marked shifts in coccolithophore assemblages closely related to the major climatic events of the Eocene-Oligocene transition. The first of these transitions, at $\sim 34.0 \mathrm{Ma}$, coincides with a distinct, $\sim 50 \mathrm{ka}$ interval of very low nannofossil abundance, the first appearance of significant reworked Cretaceous nannofossils, indicative of a marked sea level fall and a distinct cooling in sea surface temperatures (SST). It precedes the first positive shift in $\delta^{18} \mathrm{O}$ values by $\sim 150 \mathrm{ka}$. The second and larger transition, at $\sim 33.63 \mathrm{Ma}$, includes a significant and long-term reduction in the diversity of nannofossil assemblages and is closely associated with the planktonic foraminiferal extinctions at the Eocene-Oligocene boundary [Wade and Pearson, 2008]. Both of these transitions are dominated by major reductions in the relative abundance of holococcolith and other oligotrophic taxa and an increase in the relative abundance of Cyclicargolithus floridanus and 
Sphenolithus predistentus. These significant shifts contrast with the small number of existing EOT records from the low to midlatitudes, which document only a limited nannofossil response to this interval of pronounced global change [Monechi, 1986]. A large proportion of the nannofossil shift in the Tanzanian record is due to the decline of an extraordinarily abundant latest Eocene holococcolith assemblage. This is, to our knowledge, the first documentation of long-term productivity changes between the haploid and diploid coccolithophore life cycle phases in response to pronounced paleoceanographic disturbance and we interpret this as representing increased nutrient availability in the low-latitude surface ocean. Many of these fragile and dissolution-susceptible holococcolith taxa are not usually preserved in typical carbonate-rich pelagic sediments, which is one of several preservational filters that can limit our understanding of past ecological change from an analysis of moderately to poorly preserved microfossil assemblages [Bown et al., 2008a; Young et al., 2005].

[30] Contrary to previous opinion [Diester-Haass and Zachos, 2003; Salamy and Zachos, 1999; Zachos and Kump, 2005], recent carbon cycle modeling has suggested that organic carbon burial associated with increased productivity across the EOT may have played little or no role in driving either the global positive shift in $\delta^{13} \mathrm{C}$ or the rapid deepening of the $\mathrm{CCD}$, which are instead attributed to a reduction in shelf carbonate production and the weathering of exposed and relatively isotopically heavy neritic carbonates [Merico et al., 2008]. However, the calcareous nannofossil record presented here strongly indicates an increased availability of nutrients in the low-latitude surface ocean, adding to the growing number of studies that document an increase in surface ocean productivity directly coincident with the EOT [Anderson and Delaney, 2005; Diester-Haass et al., 1996; Diester-Haass and Zachos, 2003; Latimer and Filippelli, 2002; Ravizza and Paquay, 2008; Salamy and Zachos, 1999]. This discrepancy between surface ocean productivity records and the extent of organic carbon burial across the EOT needs to be addressed and may indicate a widespread decoupling of productivity and carbon burial due to the increased ventilation of the deep ocean.

[31] Acknowledgments. This research was funded by the Natural Environment Research Council and University College London Graduate School. We thank all members of the Tanzanian Drilling Project and the Tanzanian Petroleum Development Corporation for assistance with fieldwork and Jan Backman and Isabella Raffi for their constructive and insightful reviews.

\section{References}

Anderson, L. D., and M. L. Delaney (2005), Middle Eocene to early Oligocene paleoceanography from the Agulhas Ridge, Southern Ocean (Ocean Drilling Program Leg 177, Site 1090), Paleoceanography, 20, PA1013, doi:10.1029/2004PA001043.

Aubry, M. P. (1992), Late Paleogene calcareous nannoplankton evolution: A tale of climatic deterioration, in Eocene/Oligocene Climatic and Biotic Evolution, edited by D. R. Prothero and W. A. Berggren, pp. 272-309, Princeton Univ. Press, Princeton, N. J.

Berggren, W. A., and P. N. Pearson (2005), A revised tropical to subtropical Paleogene planktonic foraminiferal zonation, J. Foraminiferal Res., 35, 279-298, doi:10.2113/ 35.4.279.

Berggren, W. A., D. V. Kent, C. C. Swisher, and M. P. Aubry (1995), A revised Cenozoic geochronology and chronostratigraphy, in Geochronology, Time Scales and Global Stratigraphic Correlations: A Unified Temporal Framework for an Historical Geology, edited by W. A. Berggren, D. V. Kent, and J. Hardenbol, pp. 129-212, Soc. of Econ. Paleontol. and Mineral., Tulsa, Okla.

Billard, C. (1994), Life cycles, in The Haptophyte Algae, edited by J. C. Green and B. S. C. Leadbeater pp. 167-186, Clarendon, Oxford, U. K.

Billups, K., and D. P. Schrag (2003), Application of benthic foraminiferal $\mathrm{Mg} / \mathrm{Ca}$ ratios to questions of Cenozoic climate change, Earth Planet. Sci. Lett., 209, $181-195$, doi:10.1016/ S0012-821X(03)00067-0

Bown, P. R., et al. (2008a), A Paleogene calcareous microfossil Konservat-Lagerstätte from the Kilwa Group of coastal Tanzania, Geol. Soc. Am. Bull., 120, 3-12, doi:10.1130/ B26261.1.
Bown, P. R., T. Dunkley Jones, J. R. Young, and R. Randell (2008b), A Paleogene record of extant lower photic zone calcareous nannoplankton, Palaeontology, in press.

Bralower, T. J. (2002), Evidence of surface water oligotrophy during the PaleoceneEocene thermal maximum: Nannofossil assemblage data from Ocean Drilling Program Site 690, Maud Rise, Weddell Sea, Paleoceanography, 17(2), 1023, doi:10.1029/ 2001PA000662.

Breza, J. R., and S. W. Wise (1992), Lower Oligocene ice-rafted debris on the Kerguelen Plateau: Evidence for East Antarctic continental glaciation, Proc. Ocean Drill. Program, Sci. Results, 120, 161-178.

Broerse, A. T. C., G. J. A. Brummer, and J. E. Van Hinte (2000), Coccolithophore export production in response to monsoonal upwelling off Somalia (northwestern Indian Ocean) Deep Sea Res. Part II, 47, 2179-2205, doi:10.1016/S0967-0645(00)00021-7.

Brunner, C. A., and P. E. Biscaye (2003), Production and resuspension of planktonic foraminifers at the shelf break of the Southern Middle Atlantic Bight, Deep Sea Res. Part I, 50, 247-268, doi:10.1016/S09670637(02)00165-6.

Coccioni, R., P. Monaco, S. Monechi, M. Nocchi, and G. Parisi (1988), Biostratigraphy of the Eocene-Oligocene boundary at Massignano (Ancona, Italy), in The Eocene-Oligocene Boundary in the Marche-Umbria Basin, edited by I. Premoli SilvaR. CoccioniA. Montanari, pp. 59-80, Int. Subcomm. on Paleogene Stratigr., Ancona, Italy.

Coxall, H. K., and P. N. Pearson (2007), The Eocene-Oligocene transition, in Deep-Time Perspectives on Climate Change: Marrying the Signal From Computer Models and Biolo- gical Proxies, edited by M. Williams et al., pp 351-387, Micropalaeontol. Soc., London.

Coxall, H. K., P. A. Wilson, H. Pälike, C. H Lear, and J. Backman (2005), Rapid stepwise onset of Antarctic glaciation and deeper calcite compensation in the Pacific Ocean, Nature, 433, 53-57, doi:10.1038/nature03135.

Cros, L., A. Kleijne, A. Zeltner, C. Billard, and J. R. Young (2000), New examples of holococcolith-heterococcolith combination coccospheres and their implications for coccolithophorid biology, Mar. Micropaleontol., 39, 1-34, doi:10.1016/S03778398(00)00010-4.

Diester-Haass, L., and J. C. Zachos (2003), The Eocene-Oligocene Transition in the Equatorial Atlantic (ODP Site 925), Paleoproductivity increase and positive (13C excursion, in From Greenhouse to Icehouse: The Marine EoceneOligocene Transition, edited by D. R. Prothero, L. C. Ivany, and E. A. Nesbitt, pp 397-416, Columbia Univ. Press, New York.

Diester-Haass, L., C. Robert, and H. Chamley (1996), The Eocene-Oligocene preglacial-glacial transition in the Atlantic sector of the Southern Ocean (ODP Site 690), Mar. Geol. $131,123-149$, doi:10.1016/00253227(95)00174-3.

Dunkley Jones, T., and P. R. Bown (2007), Postsampling dissolution and the consistency of nannofossil diversity measures: A case study from freshly cored sediments of coastal Tanzania, Mar. Micropaleontol., 62, 254-268, doi:10.1016/j.marmicro.2006.09.001.

Dunkley Jones, T., P. R. Bown, and P. N. Pearson (2008), Exceptionally well preserved upper Eocene to lower Oligocene calcareous nannofossils (Prymnesiophycidae) from the Pande Formation (Kilwa Group) Tanzania, J. Syst. Palaeontol., in press. 
Funakawa, S., H. Nishi, T. C. Moore, and C. A. Nigrini (2006), Radiolarian faunal turnover and paleoceanographic change around Eocene/Oligocene boundary in the central equatorial Pacific, ODP Leg 199, Holes 1218A, 1219A, and 1220A, Palaeogeogr. Palaeoclimatol. Palaeoecol., 230, 183-203, doi:10.1016/j.palaeo.2005.07.014.

Gibbs, S., N. J. Shackleton, and J. R. Young (2004), Orbitally forced climate signals in mid-Pliocene nannofossil assemblages, Mar Micropaleontol., 51, 39-56, doi:10.1016 j.marmicro.2003.09.002

Gibbs, S., T. J. Bralower, P. R. Bown, J. C Zachos, and L. M. Bybell (2006a), Shelf and open-ocean calcareous phytoplankton assemblages across the Paleocene-Eocene Thermal Maximum: Implications for global productivity gradients, Geology, 34, 233-236, doi:10.1130/G22381.1.

Gibbs, S. J., P. R. Bown, J. A. Sessa, T. J. Bralower, and J. B. Wilson (2006b), Nannoplankton extinction and origination across the Paleocene-Eocene Thermal Maximum, Science, 314, 1770-1773, doi:10.1126/ science. 1133902 .

Goldharber, M. B. (2004), Sulfur-rich sediments, in Treatise on Geochemistry, vol. 7, Sediments, Diagenesis, and Sedimentary Rocks, edited by F. T Mackenzie pp. 257-288, Elsevier, Amsterdam.

Huber, M., H. Brinkhuis, C. E. Stickley, K. Döös, A. Sluijs, J. Warnaar, S. A. Schellenberg, and G. L. Williams (2004), Eocene circulation of the Southern Ocean: Was Antarctica kept warm by subtropical waters? Paleoceanography, 19, PA4026, doi:10.1029/ 2004PA001014

Ivany, L. C., S. Van Simaeys, E. W. Domack, and S. D. Samson (2006), Evidence for an earliest Oligocene ice sheet on the Antarctic Peninsula, Geology, 34, 377-380, doi:10.1130/G22383.1.

Jordan, R. W. (2002) Environmental applications of calcareous nannofossils, in Quaternary Environmental Micropalaeontology, edited by S. K. Haslett, pp. 185-206, Arnold, London.

Jordan, R. W., and A. H. L. Chamberlain (1997), Biodiversity among haptophyte algae, Biodiversity Conserv., 6, 131-152.

Katz, M. E., K. G. Miller, J. D. Wright, B. S. Wade, J. V. Browning, B. S. Cramer, and Y. Rosenthal (2008), Stepwise transition from the Eocene greenhouse to the Oligocene icehouse, Nat. Geosci., 1, 329-334, doi:10.1038/ ngeo 179

Kiefer, T., I. McCave, and H. Elderfield (2006), Antarctic control on tropical Indian Ocean sea surface temperatures and hydrography, Geophys. Res. Lett., 33, L24612, doi:10.1029/ 2006GL027097.

Kinkel, H., K. H. Baumann, and M. Cepek (2000), Coccolithophores in the equatorial Atlantic Ocean: Response to seasonal and Late Quaternary surface water variability, Mar. Micropaleontol., 39, 87-112, doi:10.1016/S0377-8398(00)00016-5.

Kleijne, A. (1991), Holococcolithophorids from the Indian Ocean, Red Sea, Mediterranean Sea and North Atlantic Ocean, Mar. Micropaleontol., 17, 1-76, doi:10.1016/03778398(91)90023-Y.

Latimer, J. C., and G. M. Filippelli (2002), Eocene to Miocene terrigenous inputs and export production: Geochemical evidence from ODP Leg 177, Site 1090, Palaeogeogr. Palaeocli- matol. Palaeoecol., 182, 151-164, doi:10.1016/S0031-0182(01)00493-X.

Lear, C. H., H. Elderfield, and P. A. Wilson (2000), Cenozoic deep-sea temperatures and global ice volumes from $\mathrm{Mg} / \mathrm{Ca}$ in benthic foraminiferal calcite, Science, 287, 269-287, doi:10.1126/science. 287.5451 .269

Lear, C. H., Y. Rosenthal, H. K. Coxall, and P. A. Wilson (2004), Late Eocene to early Miocene ice sheet dynamics and the global carbon cycle, Paleoceanography, 19 , PA4015, doi:10.1029/2004PA001039.

Lear, C. H., T. R. Bailey, P. N. Pearson, H. K. Coxall, and Y. Rosenthal (2008), Cooling and ice growth across the Eocene-Oligocene transition, Geology, 36, 251-254, doi:10.1130/ G24584A.1.

Lees, J. A., P. R. Bown, J. R. Young, and J. B. Riding (2004), Evidence for annual records of phytoplankton productivity in the Kimmeridge Clay Formation coccolith stone bands (Upper Jurassic, Dorset, UK), Mar. Micropaleontol., 52,29-49, doi:10.1016/ j.marmicro.2004.04.005

Liu, Z., S. Tou, Q. Zhao, X. Cheng, and W. Huang (2004), Deep-water Earliest Oligocene Glacial Maximum (EOGM) in the South Atlantic, Chin. Sci. Bull., 49, 2190-2197, doi:10.1360/04wd0228

Martini, E. (1971), Standard Tertiary and Quaternary calcareous nannoplankton zonation, in Proceedings of the Second Planktonic Conference, Roma, 1970, edited by A. Farinacci, pp. 739-785, Ed. Tecnosci., Rome.

McIntyre, A., and A. W. H. Bé (1967), Modern coccolithophoridae of the Atlantic Ocean-I. Placoliths and cyrtoliths, Deep Sea Res., 14, $561-597$

Merico, A., T. Tyrrell, and P. A. Wilson (2008), Eocene/Oligocene ocean de-acidification linked to Antarctic glaciation by sea-level fall, Nature, 452, 979-982, doi:10.1038/nature 06853 .

Miller, K. G., J. D. Wright, and R. G. Fairbanks (1991), Unlocking the ice house: OligoceneMiocene oxygen istopes, eustasy, and margin erosion, J. Geophys. Res., 96, 6829-6848, doi:10.1029/90JB02015.

Miller, K. G., J. V. Browning, M. P. Aubry, B. S. Wade, M. E. Katz, A. A. Kulpecz, and J. D. Wright (2008), Eocene-Oligocene global climate and sea-level changes: St Stephens Quarry, Alabama, Geol. Soc. Am. Bull., 120, 34 53, doi:10.1130/B26105.1.

Monechi, S. (1986), Calcareous nannofossil events around the Eocene-Oligocene boundary in the Umbrian Apennines (Italy), Palaeogeogr. Palaeoclimatol. Palaeoecol., 57, 61-69, doi:10.1016/0031-0182(86)90006-4.

Monechi, S., A. Buccianti, and S. Gardin (2000), Biotic signals from nannoflora across the iridium anomaly in the upper Eocene of the Massignano section: Evidence from statistical analysis, Mar. Micropaleontol., 39, 219-237, doi:10.1016/S0377-8398(00)00022-0

Nicholas, C. J., et al. (2006), Stratigraphy and sedimentology of the Upper Cretaceous to $\mathrm{Pa}$ leogene Kilwa Group, southern coastal Tanzania, J. Afr. Earth Sci., 45, 431-466, doi:10.1016/j.jafrearsci.2006.04.003.

Nilsen, E. B., L. D. Anderson, and M. L. Delaney (2003), Paleoproductivity, nutrient burial, climate change and the carbon cycle in the western equatorial Atlantic across the Eocene/Oligocene boundary, Paleoceanography, 18(3), 1057, doi:10.1029/2002PA000804.

Noël, M.-H., M. Kawachi, and I. Inouye (2004), Induced dimorphic life cycle of a coccolitho- phorid, Calyptrosphaera sphaeroidea (Prymnesiophyceae, Haptophyta), J. Phycol., 40 112-129.

Okada, H., and S. Honjo (1973), The distribution of oceanic coccolithophorids in the Pacific, Deep Sea Res., 20, 355-374.

Pagani, M., J. C. Zachos, K. H. Freeman, B. Tipple, and S. Bohaty (2005), Marked decline in atmospheric carbon dioxide concentrations during the Paleogene, Science, 309, 600-603, doi:10.1126/science.1110063.

Pawlowsky-Glahn, V., and J. J. Egozcue (2006), Compositional data and their analysis: An introduction, in Compositional Data Analysis in the Geosciences: From Theory to Practice, edited by A. Buccianti, G. Mateu-Figueras, and V. Pawlowsky-Glahn, pp. 1-10, Geol. Soc., London.

Pearson, P. N., P. W. Ditchfield, J. Singano, K. G. Harcourt-Brown, C. J. Nicholas, R. K Olsson, N. J. Shackleton, and M. A. Hall (2001), Warm tropical sea surface temperatures in the Late Cretaceous and Eocene epochs, Nature, 413, 481-487, doi:10.1038/ 35097000

Pearson, P. N., B. E. van Dongen, C. J. Nicholas, R. Pancost, S. Schouten, J. Singano, and B. S. Wade (2007), Stable warm tropical climate through the Eocene Epoch, Geology, 35, 211-214, doi:10.1130/G23175A.1.

Pearson, P. N., I. K. McMillan, B. S. Wade, T. Dunkley Jones, H. K. Coxall, P. R. Bown, and C. H. Lear (2008), Extinction and environmental change across the Eocene-Oligocene boundary in Tanzania, Geology, 36, 179-182, doi:10.1130/G24308A.1

Pekar, S. F., N. Christie-Blick, M. A. Kominz, and K. G. Miller (2002), Calibration between eustatic estimates from backstripping and oxygen isotopic records for the Oligocene, Geology, 30, 903-906, doi:10.1130/00917613(2002)030<0903:CBEEFB >2.0.CO;2.

Persico, D., and G. Villa (2004), Eocene-Oligocene calcareous nannofossils from Maud Rise and Kerguelen Plateau (Antarctica): Paleoecological and paleoceanographic implications, Mar. Micropaleontol., 52, 153-179, doi:10.1016/j.marmicro.2004.05.002.

Raffi, I., J. Backman, and H. Pälike (2005), Changes in calcareous nannofossil assemblages across the Paleocene/Eocene transition from the paleo-equatorial Pacific Ocean, $\mathrm{Pa}$ laeogeogr. Palaeoclimatol. Palaeoecol., 226 93-126, doi:10.1016/j.palaeo.2005.05.006.

Ravizza, G., and F. Paquay (2008), Os isotope chemostratigraphy applied to organic-rich marine sediments from the Eocene-Oligocene transition on the West African margin (ODP Site 959), Paleoceanography, 23, PA2204, doi:10.1029/2007PA001460

Rea, D. K., and M. W. Lyle (2005), Paleogene calcite compensation depth in the eastern subtropical Pacific: Answers and questions, $\mathrm{Pa}$ leoceanography, 20, PA1012, doi:10.1029/ 2004PA001064.

Ribbe, J. (2004), The southern supplier, Nature, 427, 23-24, doi:101038/427023a.

Salamy, K. A., and J. C. Zachos (1999), Latest Eocene Early Oligocene climate change and Southern Ocean fertility: Inferences from sediment accumulation and stable isotope data, Palaeogeogr. Palaeoclimatol. Palaeoecol., 145, 61-77, doi:10.1016/S00310182(98)00093-5.

Sarmiento, J. L., N. Gruber, M. A. Brzezinski, and J. P. Dunne (2004), High-latitude controls of thermocline nutrients and low latitude bio- 
logical productivity, Nature, 427, 56-60, doi:10.1038/nature02127.

Schott, F. A., and J. P. McCreary Jr. (2001), The monsoon circulation of the Indian Ocean, Prog. Oceanogr., 51, 1-123, doi:10.1016/ S0079-6611(01)00083-0.

Swallow, J. C., F. Schott, and M. Fieux (1991), Structure and transport of the East African Coastal Current, J. Geophys. Res., 96, 22,245-22,257, doi:10.1029/91JC01942.

Takahashi, K., and H. Okada (2000), Environmental control on the biogeography of modern coccolithophores in the southeastern Indian Ocean offshore of Western Australia, Mar. Micropaleontol., 39, 73-86, doi:10.1016/S03778398(00)00015-3.

Thió-Henestrosa, S., and J. A. Martín-Fernández (2006), Detailed guide to CoDaPack: A freeware compositional software, in Compositional Data Analysis in the Geosciences: From Theory to Practice, edited by A. Buccianti, G. Mateu-Figueras, and V. Pawlowsky-Glahn, pp. 101-118, Geol. Soc., London.

Thomas, E., H. Brinkhuis, M. Huber, and U. Röhl (2006), An ocean view of the Early Cenozoic Greenhouse world, Oceanography, 19, 94-103.

Wade, B. S., and P. R. Bown (2006), Calcareous nannofossils in extreme environments: The Messinian Salinity Crisis, Polemi Basin, Cyprus, Palaeogeogr. Palaeoclimatol. Palaeoe col., 233, 271-286, doi:10.1016/ j.palaeo.2005.10.007.

Wade, B. S., and H. Pälike (2004), Oligocene climate dynamics, Paleoceanography, 19 PA4019, doi:10.1029/2004PA001042.

Wade, B. S., and P. N. Pearson (2008), Planktonic foraminiferal turnover, diversity fluctua- tions and geochemical signals across the Eocene/Oligocene boundary in Tanzania, Mar. Micropaleontol., 68, 244-255.

Wei, W., and S. W. Wise (1990), Biogeographic gradients of middle Eocene-Oligocene calcareous nannoplankton in the South Atlantic Ocean, Palaeogeogr. Palaeoclimatol. $\mathrm{Pa}$ laeoecol., 79, 29-61, doi:10.1016/00310182(90)90104-F.

Wei, W., G. Villa, and S. W. Wise (1992), Paleoceanographic implications of EoceneOligocene calcareous nannofossils from Sites 711 and 748 in the Indian Ocean, Proc. Ocean Drill. Program Sci. Results, 120, 979-999.

Winter, A., R. W. Jordan, P. H. Roth (1994), Biogeography of living coccolithophores in ocean waters, in Coccolithophores, edited by A. Winter and W. G. Siesser, pp. 161-177, Cambridge Univ. Press, Cambridge, U. K.

Wise, S. W., J. R. Breza, D. M. Harwood, an W. C. Wei (1991), Paleogene glacial history of Antarctica, in Controversies in Modern Geol ogy: Evolution of Geological Theories in Sedimentology, Earth History and Tectonics, edited by D. W. Mueller, J. A. McKenzie, and $\mathrm{H}$. Weissert pp. 133-171, Academic, London.

Wise, S. W., J. R. Breza, D. M. Harwood, W. Wei, and J. C. Zachos (1992), Paleogene glacial history of Antarctica in light of leg 120 drilling results, Proc. Ocean Drill. Program Sci. Results, 120, 1001-1030.

Young, J. R., S. A. Davis, P. R. Bown, and S. Mann (1999), Coccolith ultrastructure an biomineralisation, J. Struct. Biol., 126, 195 215, doi:10.1006/jsbi.1999.4132.

Young, J. R., M. Geisen, and I. Probert (2005), A review of selected aspects of coccolitho- phore biology with implications for paleodiversity estimation, Micropaleontology, 51, 267-288, doi:10.2113/gsmicropal.51.4.267.

Zachos, J. C., and L. R. Kump (2005), Carbon cycle feedbacks and the initiation of Antarctic glaciation in the earliest Oligocene, Global Planet. Change, 47, 51-66, doi:10.1016 j.gloplacha.2005.01.001

Zachos, J. C., J. R. Breza, and S. W. Wise (1992), Early Oligocene ice-sheet expansion on Antarctica-Stable isotope and sedimentological evidence from Kerguelen Plateau, southern Indian Ocean, Geology, 20, 569 573, d o i : $10.1130 / 0091$ 7613(1992)020<0569:EOISEO >2.3.CO;2.

Zachos, J. C., T. M. Quinn, and K. A. Salamy (1996), High-resolution $\left(10^{4}\right.$ years) deep-sea foraminiferal stable isotope records of the Eocene-Oligocene climate transition, Paleoceanography, 11, 251-266, doi:10.1029/ 96PA00571.

Zachos, J., M. Pagani, L. Sloan, E. Thomas, and K. Billups (2001), Trends, rhythms, and aberrations in global climate $65 \mathrm{Ma}$ to present, Science, 292, 686-693, doi:10.1126/ science. 1059412

P. R. Bown, Department of Earth Sciences, University College London, Gower Street, London WCE 6BT, UK.

H. K. Coxall, C. H. Lear, and P. N. Pearson, School of Earth and Ocean Sciences, Cardiff University, Park Place, Cardiff CF10 3YE, UK. T. Dunkley Jones, Department of Geography, University College London, Gower Street London WCE 6BT, UK. (tom.dunkleyjones@ ucl.ac.uk)

B. S. Wade, Department of Geology and Geophysics, Texas A\&M University, College Station, TX 77843-3115, USA. 